\title{
Sustainable development indicator systems for island cities: The case of Zhoushan Maritime Garden City
}

\author{
Qianhu Chen \\ College of Civil Engineering and Architectural, Zhejiang University of Technology, China \\ chenqianhu@zjut.edu.cn
}

Hanning Dong

College of Civil Engineering and Architectural, Zhejiang University of Technology, China 416354191@qq.com (corresponding author)

\begin{abstract}
Because islands and archipelagos are often said to present distinct characteristics, there is a need to develop indicator systems for guiding and evaluating the sustainable development of island cities. This methodologically oriented study considers existing standards for urban sustainable development and uses these as the basis for selecting 70 indicators to assess the sustainability of China's Zhoushan Archipelago, bearing in mind Zhoushan's specific island and archipelago environment. The indicators are classified into ecological, social, economic, cultural, and scientific and technological dimensions. Present conditions in Zhoushan Archipelago are evaluated using statistical data. The results shows that the sustainability of Zhoushan's ecology, economic and social performance is good, while the cultural and science and technology dimensions perform relatively poorly. This study suggests future focus areas for Zhoushan's urban sustainable development as a maritime garden city.
\end{abstract}

Keywords: archipelagos, indicator systems, island cities, maritime garden city, urban sustainable development, Zhoushan

https://doi.org/10.24043/isj.103 • Received November 2018, accepted September 2019

(C) 2019-Institute of Island Studies, University of Prince Edward Island, Canada.

\section{Introduction}

This methodologically oriented paper questions how best to create an urban sustainable development indicator for China's Zhoushan Archipelago. It does so by analyzing existing urban evaluation index systems and considering how these can be adapted to Zhoushan's specific urban archipelago context and to wider characteristics of island cities. We ultimately present our own Zhoushan Maritime Garden City indicator system.

It is often said that more than half of the world's population now lives in coastal areas, and the growth is still intense (Barragán \& de Andrés, 2015). It is also often stated that, due to their relatively closed geographical locations, limited economic bases, and sensitive ecosystems, island cities may be exceptionally vulnerable to unsustainable development. It is therefore important to consider the manner in which island city sustainable development might best be achieved. 
Urban sustainable development indicator systems are seen as analytical and interpretive tools for promoting effective urban planning, construction, and management (Venturelli \& Galli, 2006). Following the 1992 Rio de Janeiro Earth Summit (UNCED), many institutions and scholars have published different definitions and methods of evaluating the concept of 'sustainable development' (Bell \& Moorse, 2008; Moldan et al, 2012; Wang et al, 2012).

The United Nations Commission on Sustainable Development (UNCSD, 2001) has established an indicator system for sustainable urban development centered on the four dimensions of economy, society, environment, and institutions (张志强等, 2002). Institutions and scholars in China have also formulated urban sustainable development indicators based on the Chinese context. The China City Development Academy (中国城市发展研究院, 2010) selected 35 indicators to evaluate the performance of China's urban sustainable development based on the three dimensions of economy, society, and living standards. Most of the scholars consulted for the purpose of that paper identified three pillars of sustainable development: environmental, economic, and social dimensions, which were integrated into the indicator system (朱丽, 2018; 孙晓等, 2016). Some scholars also added resources (郑晓云等, 2018) and technology (孙湛, 马海涛, 2018) to the three existing pillars.

However, because sustainability is dependent upon the specific environmental characteristics of the area in question, including various spatiotemporal scales, sustainability must be determined and assessed on the basis of context-specific objectives. As a result, none of the concepts and indicator systems for sustainable development have met with universal acceptance. This is particularly true for island cities, which have not always been recognized as possessing special characteristics but which may nonetheless have a tendency to combine high urban density with limits to spatial expansion (Sheng et al, 2017, p.200) as well as to development into important centres of trade, mediating the exchange of products, capital, and culture between the continental hinterland and distant places (Grydehøj, 2015). We begin by considering the context of Zhoushan Archipelago and China's island cities. We then describe existing efforts to create urban sustainable development evaluation index systems worldwide, and we compare specific index systems from both China and elsewhere. We analyse these in light of ongoing developments in Zhoushan and other island cities. We then present a Zhoushan Maritime Garden City indicator system that we have constructed using the Delphi Expert method and analytic hierarchy process (AHP) to determine weights. Finally, we evaluate Zhoushan's present-day development and advances suggestions for the future. The key points in the construction of the indicator system are shown in Figure 1. 


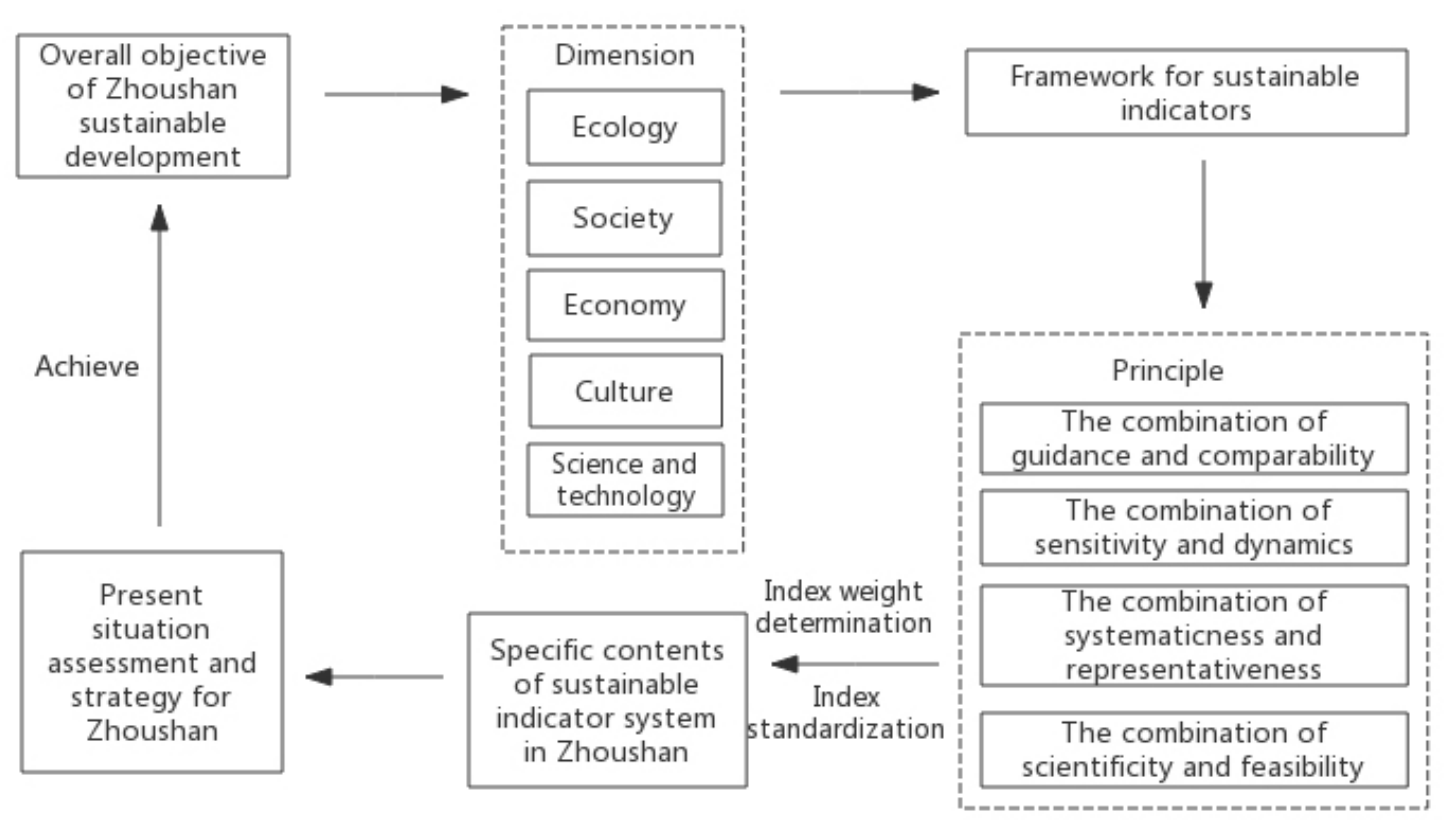

Figure 1: Key points in the construction of Zhoushan's sustainable development indicator system.

\section{Conditions in Zhoushan and Chinese island cities}

China has a very large number of islands, including numerous inhabited islands. It is rich in fisheries, tourism, ports, minerals, marine energy, marine chemical, and marine other resources, which have high security, economic, resource, and ecological and environmental values. Since the Chinese economic reform period began in the late 1970s, the economies of Chinese island cities have developed rapidly, but they remain a weak area in China's economic and social development. On the one hand, continual urbanization and development are increasing pressure on China's island cities, heightening tensions between urbanization and ecological health. The enhancement of social and economic activities and the expansion of terrestrial area through land reclamation have seriously affected the diversity of species and the quality of habitats. The transformation from farmland to built-up land has also significantly degraded agricultural ecosystems (Zhao et al, 2004; 吝涛等, 2009; Wang \& Liu, 2013; Li et al, 2011; Lin et al, 2013). On the other hand, due to the geographical location and resources of the islands themselves, there are currently problems such as weak infrastructure, economic reliance on a small number of industries, and insufficient skills in the labour market (中国自然资源部, 2018; 王晶等, 2019). As a result, China has proposed the construction of an 'ecological civilization' and a strategy for introducing talent to promote the sustainable development of island cities. That is, any tensions between urbanization and ecological health can be transformed into synergies, in which urban sustainable development supports wider efforts to maintain ecological values.

Zhoushan Archipelago is a prefecture-level city that is formed by islands and is located in the northeast of China's Zhejiang Province. The archipelago has the longest deep-water coastline in the country and forms a hub between the national north-south coastal shipping lines and inland shipping along the Yangtze River system, serving as a maritime a gateway for the Yangtze 
River Delta and opening out toward the wider world with shipping connections with emerging port cities of the Asia-Pacific region. Figure 2 shows the geographical location of Zhoushan.

In 2011, China's State Council officially approved the establishment of Zhejiang Zhoushan Archipelago as a National New Area 国家新区, making it the first New Area in China to focus on development of the marine economy. This was followed by the construction in Zhoushan of Asia's largest iron ore transit base and the country's largest commercial oil terminal. However, in recent years, the growth rate of fiscal revenues, fixed asset investments, and total retail sales of consumer goods in the archipelago have been decreasing, revealing that, like other islands in China, Zhoushan Archipelago possesses insufficient economic development momentum at the same time as it is coming under increasing pressure in terms of resource consumption and environmental burdens, which combine to threaten its sustainable development. This led to the proposal of a master plan for the Zhejiang Zhoushan Archipelago New Area 浙江舟山群岛新 区（城市）总体规划 (2012-2030) and advanced the concept of the 'maritime garden city' in order to cope with the challenges brought about by the archipelago's urbanization and to integrate national strategic expectations into Zhoushan's urban planning. In 2017, Zhoushan City issued $A$ Guide to the Construction of the Maritime Garden City 关于建设海上花园城的指导意见, which set forth the city's future development in the direction of an archipelagic, internationally oriented, and high-quality maritime garden city. This overarching objective was then broken down into five sub-categories focused on creating an "eco-harmonious green city, peoplecentered sharing city, multi-inclusive open city, cultural-characteristic friendly city and sustainable smart city” (舟山市政府, 2017).

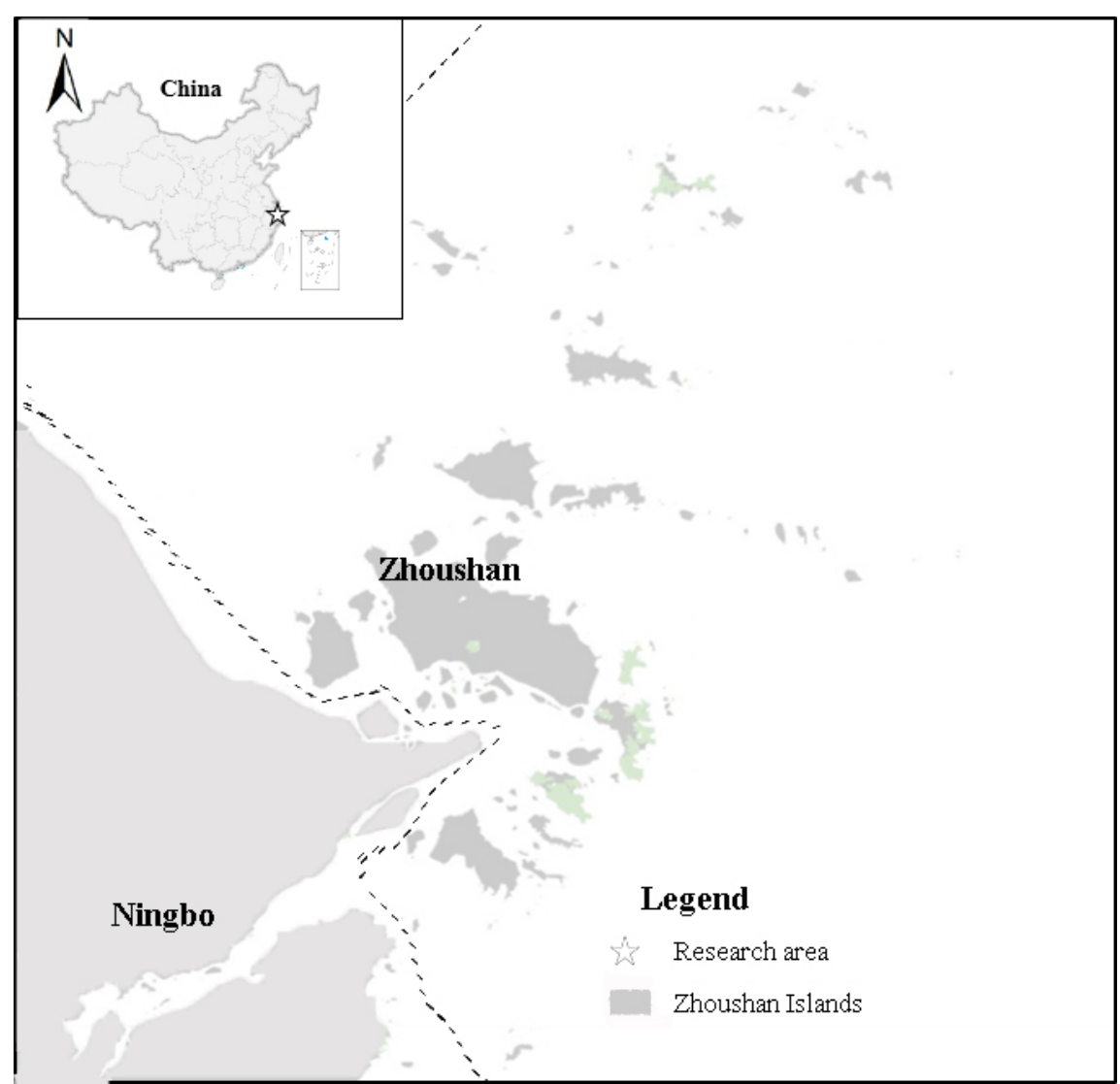

Figure 2: Location of Zhoushan Archipelago. Source: (C) Authors. 
On their own, of course, these five objectives are little more than buzzwords. In line with the Chinese approach to evidence-based policymaking, however, such abstract political objectives are given content and value by research such as that presented in this article. Thus, for example, concepts such as the aforementioned 'Ecological Civilization' are given national, regional, or local political priority, and researchers then seek to give these concepts meaning and make them productive at various spatial scales (e.g. Shen, 2013 Liu et al, 2009; Jin, 2008). This process possesses a degree of circularity, but it has the benefit of granting humanities, social sciences, and natural sciences research a crucial role in Chinese policy development and implementation.

The Maritime Garden City is a mode of urban construction integrating the concepts of the 'ecological city' and the 'public city' (吴一洲等, 2013) as well as characteristics of island cities, with specific reference to Zhoushan's archipelagic conditions. The 'ecological city' emphasizes the principle of harmony between humans and nature (丁玉洁, 2009), while the 'public city' emphasizes the necessity of subdividing urban public services, providing flexible land use, and facilitating fairer and more equitable urban layouts. Because the plan for Zhoushan as a maritime garden city is intended to be carried out along scientific lines and in accordance with reasonable standards, it could be helpful to create an urban sustainable development indicator system that is suited to island and archipelagic conditions.

These objectives may be laudable, but one of the greatest obstacles to implementing sustainable development has long been the lack of tools to assess sustainable development initiatives (Lee \& Huang, 2007). Establishing a set of indicator systems that can guide and evaluate urban sustainable development is thus an important factor for successfully constructing Zhoushan as a maritime garden city.

This is particularly important given that island and archipelago status have not always been recognised as significant in planning, that mainland-oriented urban planning is not always appropriate in island environments, and that island and archipelago spaces play a strong role in conditioning urbanization (Johnson, 2019; Larjosto, 2019; Grydehøj \& Casagrande, 2019; Fernandes \& Pinho, 2017; Grydehøj, 2015). At the same time, however, it is recognized that centering 'islandness' in sustainable development planning poses certain risks related to pursuit of goals that are especially quantifiable, achievable, and/or visible within strictly bordered island spaces (Grydehøj \& Kelman, 2017, 2016; Baldacchino \& Kelman, 2014). The aim is thus to determine means of directing and assessing urban island sustainability that transcend superficial solutions.

\section{Data and methods}

\section{Framework for sustainable indicators}

Since the 1990s, the focus of sustainable development research has shifted from definition to evaluation, especially through the construction of indicator systems (李天星, 2013). Different island cities have different developmental objectives due to their different resource endowments. In the years since the 1992 Earth Summit (UNCED, 1992), researchers and international organizations have increasingly deployed the concepts of 'social sustainability', 'economic sustainability', 'environmental sustainability', and even 'cultural sustainability' to explore different dimensions of sustainable development (Cochrane, 2006; Plummer, 1996; Hardoy et al, 1992). Advances in science and technology such as 'clean-tech' make for shifting premises of urban development and are key to promoting urban sustainable development worldwide (吴忠泽, 2006; Caprotti \& Federico, 2016). 
In light of Zhoushan's developmental trajectory, this paper focuses on the five dimensions of ecology, society, economy, culture, and science and technology to construct an indicator framework that draws upon comprehensive standards developed in a wide range of national contexts as well as the work of numerous scholars. According to this framework, Zhoushan Maritime Garden City can be said to have five overarching objectives. We have built the Zhoushan Maritime Garden City indicator system as follows (Figure 3):

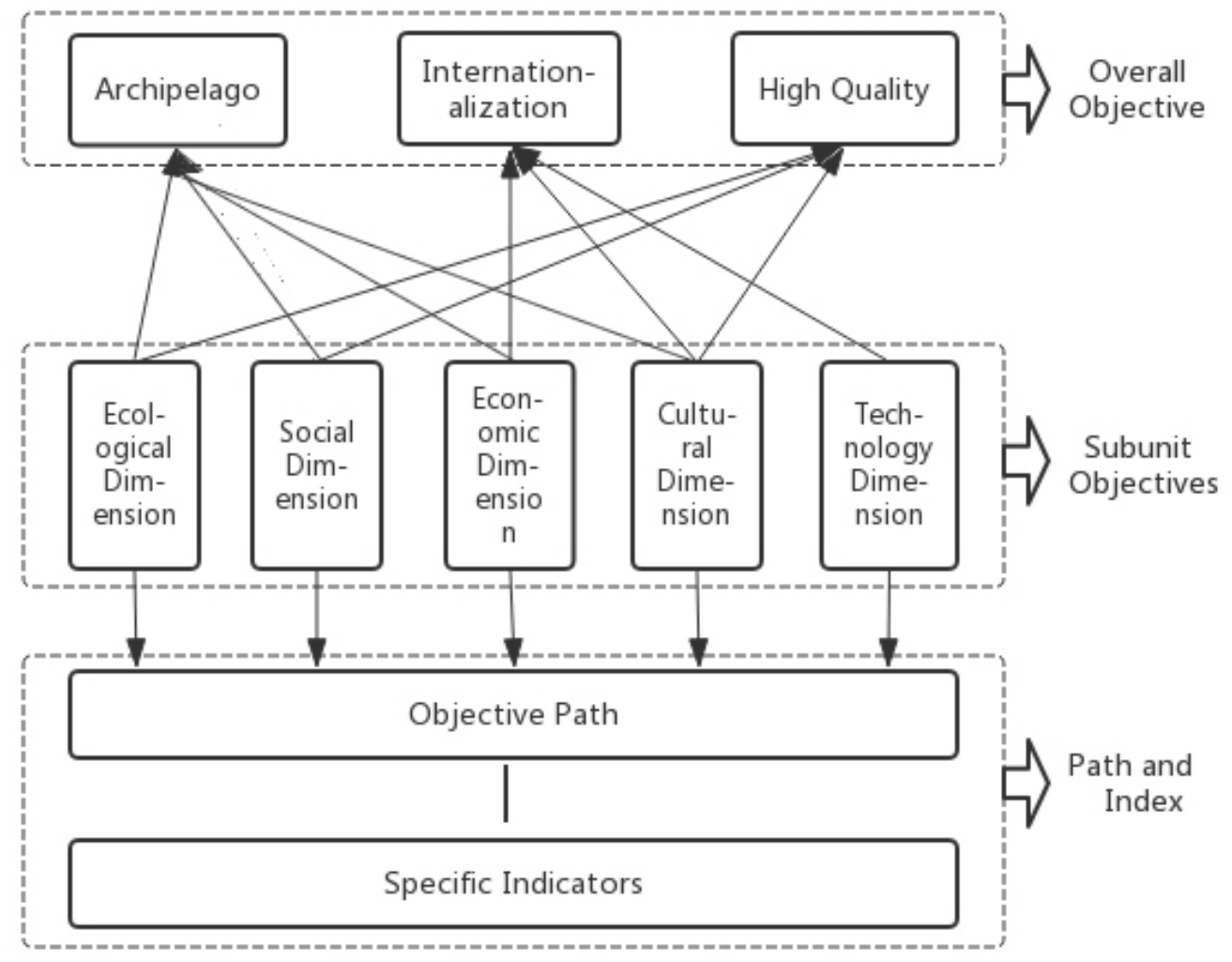

Figure 3: Framework for Zhoushan's sustainable development indicator system.

Analyzing the characteristics of sustainable development indicators

With the popularization of the concept of sustainable development, various international agencies and national governments have developed indicator frameworks and assessment tools to evaluate the status and trends related to urban sustainability performance (Briassoulis, 2001; Davison, 1996). Sustainability indicators should be flexible and dependent on the local context.

For the purposes of this research, we have selected indicator systems developed by authoritative institutions and cities with high-scoring sustainable development indices and have summarized the indicators for the five aforementioned aspects of ecology, society, economy, culture, and science and technology (Table 1). It is noteworthy that although many cities possess similar sustainable development goals, the various indicator systems emphasize these goals differently, in accordance with their specific developmental directions. In addition, environmental and social dimensions receive the most emphasis in the earliest indicator systems, with more and more cities choosing to incorporate within sustainable development the concept of scientific and technological innovation as time passes. 
Table 1: A comparison of urban sustainable development index systems. ' $V$ ' means that this indicator is included in the indicator system. Source: (C) Authors.

\begin{tabular}{|c|c|c|c|c|c|c|c|c|c|}
\hline Dimension & Indicator & $\begin{array}{c}\text { UNCSD } \\
(2001)\end{array}$ & $\begin{array}{l}\text { Global } \\
\text { Cities } \\
\text { Index } \\
(2008)\end{array}$ & $\begin{array}{r}\text { Mel- } \\
\text { bourne } \\
(2016)\end{array}$ & $\begin{array}{l}\text { Singa- } \\
\text { pore } \\
(2015)\end{array}$ & $\begin{array}{l}\text { Hong } \\
\text { Kong } \\
(2007)\end{array}$ & $\begin{array}{l}\text { Shen- } \\
\text { zhen } \\
(2017)\end{array}$ & $\begin{array}{c}\text { Beijing } \\
(2016)\end{array}$ & $\begin{array}{l}\text { Shang- } \\
\text { hai } \\
(2017)\end{array}$ \\
\hline \multirow{7}{*}{ Ecological } & Air quality & $\sqrt{ }$ & $\sqrt{ }$ & $\sqrt{ }$ & $\sqrt{ }$ & $\sqrt{ }$ & $\sqrt{ }$ & $\sqrt{ }$ & $\sqrt{ }$ \\
\hline & Forest coverage rate & $\sqrt{ }$ & & $\sqrt{ }$ & $\sqrt{ }$ & $\sqrt{ }$ & & $\sqrt{ }$ & $\sqrt{ }$ \\
\hline & Greenery coverage of non-built areas & $\sqrt{ }$ & & $\sqrt{ }$ & & $\sqrt{ }$ & $\sqrt{ }$ & $\sqrt{ }$ & \\
\hline & Blue-green space proportion & $\sqrt{ }$ & & & $\sqrt{ }$ & & & $\sqrt{ }$ & $\sqrt{ }$ \\
\hline & Surface water environmental quality & $\sqrt{ }$ & $\sqrt{ }$ & & & $\sqrt{ }$ & $\sqrt{ }$ & $\sqrt{ }$ & $\sqrt{ }$ \\
\hline & Sewage utilization rate & $\sqrt{ }$ & $\sqrt{ }$ & $\sqrt{ }$ & $\sqrt{ }$ & $\sqrt{ }$ & $\sqrt{ }$ & $\sqrt{ }$ & \\
\hline & Waste recycling rate & & $\sqrt{ }$ & & $\sqrt{ }$ & $\sqrt{ }$ & $\sqrt{ }$ & & \\
\hline \multirow{9}{*}{ Social } & Per capita emergency shelter area & & & & & & & $\sqrt{ }$ & $\sqrt{ }$ \\
\hline & $\begin{array}{l}\text { Community-life circle system 社区 } \\
\text { 生活圈 coverage }\end{array}$ & & & $\sqrt{ }$ & & & & $\sqrt{ }$ & $\sqrt{ }$ \\
\hline & $\begin{array}{l}\text { Accessibility of community health } \\
\text { services }\end{array}$ & & & $\sqrt{ }$ & & & & & $\sqrt{ }$ \\
\hline & Green traffic proportion & & $\sqrt{ }$ & $\sqrt{ }$ & $\sqrt{ }$ & & $\sqrt{ }$ & $\sqrt{ }$ & $\sqrt{ }$ \\
\hline & Food safety qualification rate & & & & $\sqrt{ }$ & & $\sqrt{ }$ & $\sqrt{ }$ & \\
\hline & Jobs-housing balance & & $\sqrt{ }$ & & & $\sqrt{ }$ & & & $\sqrt{ }$ \\
\hline & Volume of affordable housing & & & $\sqrt{ }$ & & & & & \\
\hline & The scenic spot area & & & & & $\sqrt{ }$ & & & \\
\hline & Accessibility of public spaces & & $\sqrt{ }$ & $\sqrt{ }$ & $\sqrt{ }$ & $\sqrt{ }$ & & $\sqrt{ }$ & $\sqrt{ }$ \\
\hline \multirow{6}{*}{ Economic } & GDP per capita & $\sqrt{ }$ & $\sqrt{ }$ & $\sqrt{ }$ & & & & & \\
\hline & Disposable income & & & & & & $\sqrt{ }$ & & \\
\hline & Foreign direct investment amount & $\sqrt{ }$ & & & & & & & \\
\hline & Imports and exports & $\sqrt{ }$ & & $\sqrt{ }$ & & & & & \\
\hline & Tourism industry & $\sqrt{ }$ & & $\sqrt{ }$ & & & & $\sqrt{ }$ & $\sqrt{ }$ \\
\hline & Number of overseas urban routes & & & $\sqrt{ }$ & & & & & $\sqrt{ }$ \\
\hline \multirow{6}{*}{ Cultural } & $\begin{array}{l}\text { Area of historical and cultural } \\
\text { landscape conservation area }\end{array}$ & & & & & $\sqrt{ }$ & & & $\sqrt{ }$ \\
\hline & $\begin{array}{l}\text { Number of urban intangible cultural } \\
\text { heritage 非物质文化遗产 sites }\end{array}$ & & & $\sqrt{ }$ & & $\sqrt{ }$ & & & \\
\hline & $\begin{array}{l}\text { Number of international sports } \\
\text { events, conferences and exhibitions }\end{array}$ & & $\sqrt{ }$ & $\sqrt{ }$ & & & & $\sqrt{ }$ & \\
\hline & Number of registered volunteers & & & & $\sqrt{ }$ & & & $\sqrt{ }$ & \\
\hline & Barrier-free facility rates & & & $\sqrt{ }$ & & $\sqrt{ }$ & & & \\
\hline & Accessibility of public cultural facilities & & $\sqrt{ }$ & $\sqrt{ }$ & & & $\sqrt{ }$ & $\sqrt{ }$ & $\sqrt{ }$ \\
\hline \multirow{4}{*}{$\begin{array}{l}\text { Science and } \\
\text { Technology }\end{array}$} & $\begin{array}{l}\text { Research expenditure as a share of } \\
\text { GDP }\end{array}$ & & & $\sqrt{ }$ & & $\sqrt{ }$ & $\sqrt{ }$ & $\sqrt{ }$ & $\sqrt{ }$ \\
\hline & Ownership of 10,000 patents & & & $\sqrt{ }$ & & & $\sqrt{ }$ & $\sqrt{ }$ & \\
\hline & $\begin{array}{l}\text { Number of research and } \\
\text { development personnel in the } \\
\text { employment population }\end{array}$ & & & $\sqrt{ }$ & & & $\sqrt{ }$ & & $\sqrt{ }$ \\
\hline & $\begin{array}{l}\text { Contribution of big data in urban } \\
\text { governance and emergency } \\
\text { management }\end{array}$ & & & $\sqrt{ }$ & & & & & \\
\hline
\end{tabular}

Although the indicators are not consistent for the different cities, there are significant patterns. In terms of developmental standards in both China and overseas, the following three 
aspects emerge as most important: 1) natural conditions of non-built areas, such as forest coverage rate; 2) green and low-carbon level of built environment, such as greenery coverage; and 3) advanced environmental management mechanisms, such as waste recycling rate. The key indicators for social dimensions are: 1) degree of urban safety, such as food safety and hygiene; 2) lifestyle convenience, such as availability of housing in the vicinity of employment; 3) traffic conditions, such as the number of people who choose 'green travel'; and 4) healthy leisure options, such as green fields and public spaces. The indicators for the economic dimension focus primarily on 1) aspects of inclusive economic growth (such as GDP per capita) and 2) extent of internationalization in imports and exports. The cultural dimension indicators focus on: 1) cultural heritage, 2) accessibility of historical sites, and 3) international competition. The scientific and technological dimension is mainly considered in terms of: 1) scientific and technological skills, 2) scientific research sites, and 3) big data and IT.

The breadth of the concept of sustainable development inevitably complicates efforts to assess the suitability of sustainable development indicators (systems), while varying data availability may hinder comparisons. The United Nations Commission on Sustainable Development (UNSCD, 2001) proposed selection principles for sustainable development indicators: 1) national level, in terms of scale and scope; 2) relevance for assessment of the main objectives of the sustainable development process; 3 ) understandable, clear, and clearly defined; 4) within the capacity of the national government; 5) conceptually reasonable; 6) limited quantity of indicators, which can be modified according to future needs; 7) comprehensive screening of Agenda 21 and all aspects of sustainable development; 8) internationally consistent representation; and 9) data available at reasonable cost and able to be updated regularly. OECD $(1998,2001)$ indicates that the selection of sustainability indicators should follow three principles: policy relevance, rationality of analysis, and measurability. In light of the various requirements of sustainable development assessments and indices worldwide, aiming to transcend the single-minded pursuit of economic growth, we determined that Zhoushan City's sustainable development index should have the following characteristics:

1. A combination of guidance and comparability: the indicators should be related to current and future urban development policies and reflect the characteristics of the current historical stage (Gibson, 2006; Spangenberg, 2010; Maclaren, 1996) and be decomposed and evaluated on the basis of the specific cities' sustainable development objectives (吴凡, 2017). In order to facilitate comparison, it is also necessary to consciously select shared indicators in both China and overseas.

2. Sensitive to dynamics and change: indicators should be able to sensitively reflect systemic variation and realize dynamic urban monitoring and evaluation at diverse spatiotemporal scales (Ukaga \& Maser, 2004; Spangenberg et al, 2002; 吴凡, 2017).

3. Systematic and representative: indicators should be able to fully and systematically reflect the overall urban development situation (Gibson, 2006; Barrera-Roldán \& Saldivar-Valdés, 2003; Maclaren, 1996). There should not be an excessive number of indicators, and key points should be highlighted.

4. Scientific and feasible: the indicator system should be constructed on the basis of scientific research and argumentation. At the same time, we should consider the feasibility of investigation, evaluation, and statistics as much as possible to make the selected indicators easy to quantify (Gibson, 2006; Barrera-Roldán \& Saldivar-Valdés, 2003). 
5. Adapted to local conditions: the index system should be constructed in light of Zhoushan's status as a strongly archipelagic island city, a city type with special urban characteristics. For example, in terms of the economic dimension, the multiple maritime economic systems that can express the sustainable development of maritime industries and island tourism should be included. At the level of indicators, it is necessary to include island and archipelago characteristics, such as inter-island and island-mainland transport, to the traffic conditions field.

\section{Selection of specific sustainable development indicators}

This study uses as a reference the hierarchical structure model in the analytic hierarchy process (AHP) (Saaty, 2014). Through the above analysis, we defined the structure and constituent elements of urban sustainable development goals. Then, in accordance with the meanings and characteristics of sustainable development described in the theoretical literature, as provided in citations earlier, a large-scale questionnaire survey was conducted on administrative officials, and an initial indicator set was selected using the frequency statistics method. This indicator was then sent to experts for review and comment. Finally, the index system framework for developing Zhoushan Maritime Garden City was created in accordance with the relevant principles of index selection. The framework was expanded through recourse to the structure of the target, criterion, and indicator layers in AHP and was divided into four levels: (A) Target Layer, (B) Dimension Layer, (C) Domain Layer, and (D) Indicator Layer.

This paper's Zhoushan sustainable development indicator system is as follows:

(A) Target Layer: the overall objective of Zhoushan Maritime Garden City development.

(B) Dimension Layer: the five dimensions of ecology, society, economy, culture, and science and technology, corresponding to the sub-goals of Zhoushan Maritime Garden City development.

(C) Field Layer: in accordance with the above analysis of existing standards and Zhoushan's urban planning trajectory, 16 fields were selected (including superior natural conditions, green and low-carbon urban development, and advanced environmental management mechanisms).

(D) Indicator Layer: in order to ensure indicator accuracy and representativeness, determination of specific indicators should be based on the existing practical experience. Then, in accordance with the developmental stage, direction of reforms, resource endowments, and other existing conditions in Zhoushan Archipelago, we set forth specific indicators, modified for ease of evaluation within the index. At each domain layer, the expert advice, public participation, and statistical methods acquired through existing domestic and international standards of reference are crucial. As shown in Table 1, we use cities such as Singapore, Hong Kong, and Beijing to verify the indicator layer and its specific contents.

The selected indicators reflect Zhoushan's current developmental status and future developmental potential, and three to eight representative indicators are selected for each indicator layer. The specific indicators are shown in Table 2. 
Table 2: Sustainable development indicator system for Zhoushan Maritime Garden City.

\begin{tabular}{|c|c|c|c|}
\hline $\begin{array}{l}\text { Target } \\
\text { Layer (A) }\end{array}$ & $\begin{array}{l}\text { Dimension } \\
\text { Layer (B) }\end{array}$ & $\begin{array}{l}\text { Domain } \\
\text { Layer (C) }\end{array}$ & Indicator Layer (D) \\
\hline \multirow{9}{*}{$\begin{array}{l}\text { Sustainable } \\
\text { Develop- } \\
\text { ment } \\
\text { Indicator } \\
\text { System for } \\
\text { Zhoushan } \\
\text { Maritime } \\
\text { Garden } \\
\text { City }\end{array}$} & \multirow{3}{*}{$\begin{array}{l}\text { B1 } \\
\text { Ecology } \\
\text { (Ecologically } \\
\text { Harmonious } \\
\text { Green City) }\end{array}$} & $\begin{array}{l}\text { C1 } \\
\text { Superior } \\
\text { Natural } \\
\text { Conditions }\end{array}$ & $\begin{array}{l}\text { D1 Blue-green space proportion; D2 Proportion of days } \\
\text { with good air quality a year; D3 Forest coverage ratio; D4 } \\
\text { Proportion of good water quality in coastal waters; D5 } \\
\text { Proportion of permanent natural shoreline }\end{array}$ \\
\hline & & $\begin{array}{l}\text { C2 } \\
\text { Green and } \\
\text { Low- } \\
\text { Carbon Built } \\
\text { Environment }\end{array}$ & $\begin{array}{l}\text { D6 Greenery coverage in non-built areas; D7 Ratio of } \\
\text { shady green streets; D8 Proportion of green construction } \\
\text { among new buildings; D9 Built-up area 'sponge city'海绵 } \\
\text { 城市 coverage ratio }\end{array}$ \\
\hline & & $\begin{array}{l}\text { C3 } \\
\text { Advanced } \\
\text { Environmental } \\
\text { Management } \\
\text { Mechanisms } \\
\end{array}$ & $\begin{array}{l}\text { D10 Restoration rate of ecological space; D11 Waste } \\
\text { recycling ratio; D12 Renewable water utilization ratio; } \\
\text { D13 Street cleanliness; D14 Public satisfaction with quality } \\
\text { of ecological environment }\end{array}$ \\
\hline & \multirow{4}{*}{$\begin{array}{l}\text { B2 } \\
\text { Society } \\
\text { (People- } \\
\text { Centered } \\
\text { Sharing City) }\end{array}$} & $\begin{array}{l}\text { C4 } \\
\text { High-Security } \\
\text { City }\end{array}$ & $\begin{array}{l}\text { D15 Coverage density of 'Blue Eye in the Sky' 天眼; D16 } \\
\text { Per capita emergency shelter area; D17 Food safety and } \\
\text { hygiene ratio at agricultural market; D18 Proportion of } \\
\text { hazardous chemical facilities }\end{array}$ \\
\hline & & $\begin{array}{l}\text { C5 } \\
\text { High-Quality } \\
\text { Livable City }\end{array}$ & $\begin{array}{l}\text { D19 '15-minute community-life circle system’ } 15 \text { 分钟社 } \\
\text { 区生活圈覆盖率 coverage; D20 Average one-way } \\
\text { commute time for residents; D21 Urban security room } \\
\text { accounted for the total proportion of the city's housing }\end{array}$ \\
\hline & & $\begin{array}{l}\text { C6 } \\
\text { Walking + } \\
\text { Bus City }\end{array}$ & $\begin{array}{l}\text { D22 Density of non-industrial area support network; D23 } \\
\text { Density of city sidewalk and bike lanes; D24 Proportion of } \\
\text { urban public transport trips; D25 Bus station } 300 \mathrm{~m} \text { service } \\
\text { radius coverage; D26 Convenience degree of inter-island } \\
\text { contact }\end{array}$ \\
\hline & & $\begin{array}{l}\text { C7 } \\
\text { Healthy } \\
\text { Leisure City }\end{array}$ & $\begin{array}{l}\text { D27 Number of city parks per } 10,000 \text { people; D28 Length } \\
\text { of green corridor; D29 Coverage ratio of public spaces } \\
\text { with over } 400 \mathrm{~m}^{2} \text { of green space and public squares space } \\
\text { within } 5 \text { minutes' walk; D30 Proportion of residents who } \\
\text { can reach sea or mountain within } 15 \text { minutes; D31 Density } \\
\text { of dynamic streets in built environment; D32 Per capita } \\
\text { public sports land area; D33 Number of internationally } \\
\text { renowned business brands; D34 Per capita area of Class 3A } \\
\text { and Class 4A Tourist Spots in China }\end{array}$ \\
\hline & \multirow{2}{*}{$\begin{array}{l}\text { B3 } \\
\text { Economy } \\
\text { (Multi-Inclusive } \\
\text { Open City) }\end{array}$} & $\begin{array}{l}\text { C8 } \\
\text { Inclusive } \\
\text { Economic } \\
\text { Growth } \\
\end{array}$ & $\begin{array}{l}\text { D35 Per capita GDP; D36 Per capita disposable income of } \\
\text { urban and rural permanent residents; D37 Ratio of } \\
\text { incomes of urban and rural residents; D38 Gini coefficient }\end{array}$ \\
\hline & & $\begin{array}{l}\text { C9 } \\
\text { International } \\
\text { Open } \\
\text { Gateway }\end{array}$ & $\begin{array}{l}\text { D39 Annual growth in trade with countries along the Belt } \\
\text { and Road 一 带一路; D } 40 \text { National proportion of } \\
\text { maritime bulk commodity trade; D41 Per capita annual } \\
\text { actual utilization of foreign capital scale; D42 Number of } \\
\text { top- } 500 \text { companies in the world in this city; D43 Number } \\
\text { of overseas passenger routes; D44 Maritime economy as } \\
\text { proportion of GDP }\end{array}$ \\
\hline
\end{tabular}




\begin{tabular}{|c|c|c|}
\hline & $\begin{array}{l}\text { C10 } \\
\text { Multiple } \\
\text { Marine } \\
\text { Economic } \\
\text { Systems }\end{array}$ & $\begin{array}{l}\text { D45 Added value of maritime emerging industries } \\
\text { accounts as proportion of GDP; D46 Added value of } \\
\text { maritime finance accounts as proportion of GDP; D47 } \\
\text { Quantity of transported maritime freight; D48 Maritime } \\
\text { tourism index: annual tourism income and per capita } \\
\text { tourism consumption level }\end{array}$ \\
\hline \multirow{3}{*}{$\begin{array}{l}\text { B4 } \\
\text { Culture } \\
\text { (Culturally } \\
\text { Friendly City) }\end{array}$} & $\begin{array}{l}\text { C11 } \\
\text { High } \\
\text { Historical and } \\
\text { Cultural } \\
\text { Heritage }\end{array}$ & $\begin{array}{l}\text { D49 Number of instances of urban intangible cultural heritage } \\
\text { 非物质文化遗产数量; D50 Area of urban historical and } \\
\text { cultural landscape conservation zone; D51 Number of } \\
\text { island-characteristic fishing villages in urban areas }\end{array}$ \\
\hline & $\begin{array}{l}\text { C12 } \\
\text { High Cultural } \\
\text { Communi- } \\
\text { cation }\end{array}$ & $\begin{array}{l}\text { D52 Number of international sister cities; D53 Annual } \\
\text { overseas visitor numbers; D54 Number of international } \\
\text { and national sports events, festivals, conferences, and } \\
\text { exhibitions; D55 Ratio of registered volunteers among the } \\
\text { permanent population }\end{array}$ \\
\hline & $\begin{array}{l}\text { C13 } \\
\text { High Facility } \\
\text { Friendliness }\end{array}$ & $\begin{array}{l}\text { D56 Prevalence of barrier-free facilities in public places; } \\
\text { D57 Bus bilingualism ratio; D58 Number of public } \\
\text { cultural facilities per } 100,000 \text { people; D59 Friendly } \\
\text { community creation rate }\end{array}$ \\
\hline \multirow{3}{*}{$\begin{array}{l}\text { B5 } \\
\text { Science and } \\
\text { Technology } \\
\text { (Sustainable } \\
\text { Smart City) }\end{array}$} & $\begin{array}{l}\text { C14 } \\
\text { Maritime } \\
\text { Science } \\
\text { Center City }\end{array}$ & $\begin{array}{l}\text { D60 Total social research and experimental development } \\
\text { expenditure as proportion of GDP; D61 Total value of } \\
\text { maritime science and technology funds; D62 Number of } \\
\text { national and provincial maritime science and technology } \\
\text { laboratories; D63 Building area of centers for business } \\
\text { startups and innovation per capita; D64 Application rate of } \\
\text { maritime scientific and technological achievements; D65 } \\
\text { Proportion of maritime science and technology patents }\end{array}$ \\
\hline & $\begin{array}{l}\text { C15 } \\
\text { Maritime } \\
\text { Innovation } \\
\text { Skills Center }\end{array}$ & $\begin{array}{l}\text { D66 Number of high-skilled maritime science and } \\
\text { technology individuals per } 10,000 \text { people; D67 Number of } \\
\text { researchers per } 10,000 \text { employed population }\end{array}$ \\
\hline & $\begin{array}{l}\text { C16 } \\
\text { Smart } \\
\text { Management } \\
\text { Demonstration } \\
\text { Cities }\end{array}$ & $\begin{array}{l}\text { D68 5G network coverage; D69 Intention to build 'Ocean } \\
\text { City Smart Brain' 海洋城市智慧大脑; D70 Proportion of } \\
\text { scenic spots with smart management }\end{array}$ \\
\hline
\end{tabular}

\section{Index weight determination}

The weights of the indicators reflect their relative importance within the overall sustainability assessment. The diversity of developmental contexts means that different cities confront different challenges and possess different opportunities, resulting in varying degrees of importance for each indicator within different cities' urban sustainable development indicator systems. We thus adopt a mixed qualitative and quantitative, subjective and objective evaluation method, which is based primarily on AHP and assisted by the Delphi expert method (Linstone \& Turoff, 1976). In addition, we enlisted a number of scholars from Zhejiang University and Zhejiang University of Technology, research experts in urban planning and tourism planning, and relevant government employees to fill in a Zhoushan Maritime Garden City Construction of Indicator Relative Importance Expert Score Table. A total of 14 expert questionnaires were sent out, 12 of which were recovered, and 10 of which were valid, resulting in an effective recovery rate of $71.4 \%$. In 
dealing with the valid questionnaires, we first classified the evaluation team into three categories in accordance with their understandings of the construction of the Maritime Garden City and then gave different weight values to their evaluation opinions (Table 3). Then we used a 1-9 Likert scale to score the importance of the various factors and thereby to co-construct the importance index judgment matrix. Finally, the index weight was determined with reference to local conditions and changes over time. (For specific steps in this process, please see Brunelli, 2015.)

Table 3: The weight values of different experts.

\begin{tabular}{|c|c|c|c|}
\hline $\begin{array}{l}\text { Expert } \\
\text { Category }\end{array}$ & $\begin{array}{l}\text { No. of } \\
\text { Experts }\end{array}$ & Weight & Notes \\
\hline I & 2 & 0.25 & \multirow{3}{*}{$\begin{array}{l}\text { I: theoretical research scholars studying urban planning } \\
\text { II: urban planning, tourism planning, and landscape } \\
\text { architecture professionals } \\
\text { III: government employees }\end{array}$} \\
\hline II & 3 & 0.1 & \\
\hline III & 5 & 0.04 & \\
\hline
\end{tabular}

The weights of the five dimensions are ecology (0.24), society (0.29), economy (0.17), culture (0.15), and science and technology (0.15). After assigning the data to a percentage system, the 16 fields have an average score of 6.25. The above-average fields include the ecological dimensions of Superior Natural Conditions (C1), Green and Low-Carbon Built Environment (C2), and Advanced Environmental Management Mechanisms (C3); the social dimensions of High-Quality Livable City (C5) and Healthy Leisure City (C7); the economic dimension of the International Open Gateway (C9); the cultural dimension of High Cultural Communication (C12); and the science and technology dimension of Maritime Science Center City (C14). This indicates that these aspects could help set the strategic direction for the Zhoushan Maritime Garden City's future development.

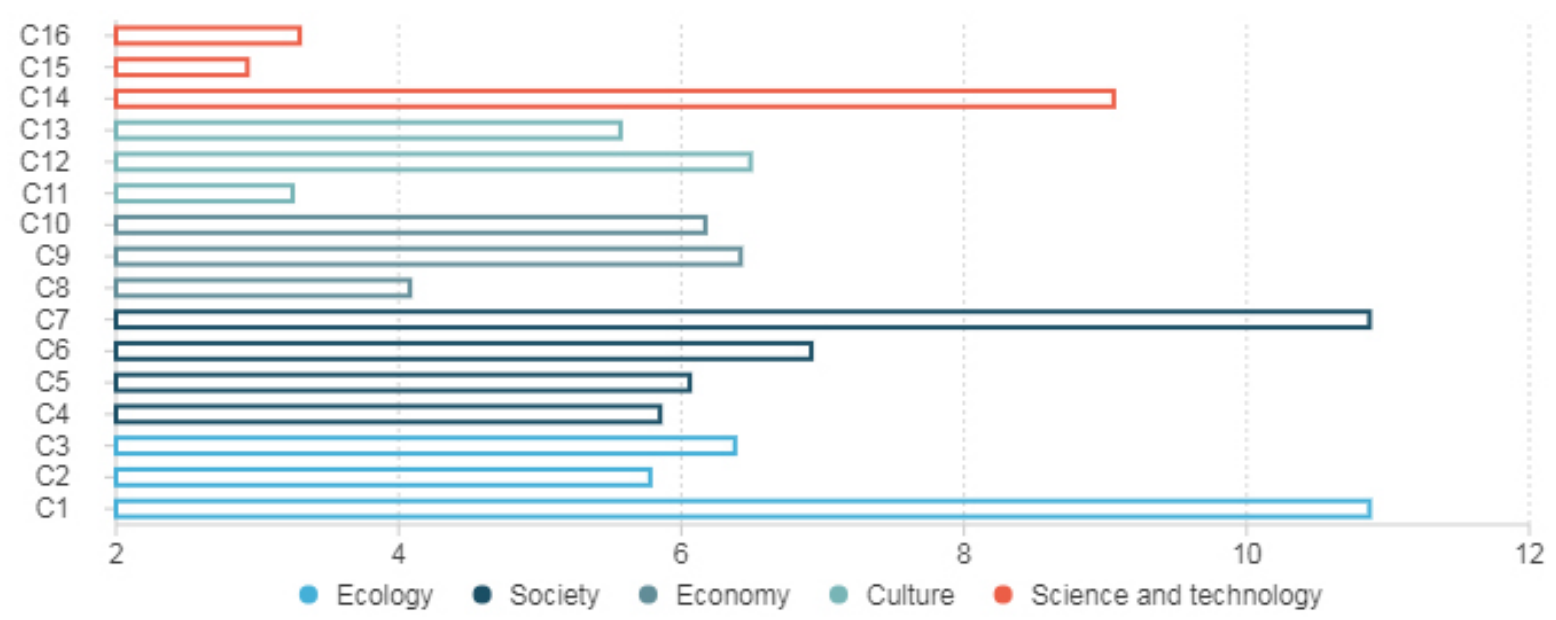

Figure 4: Assignment score for each field.

\section{Index standardization}

After having established the specific indicator system, the current data can be standardized to render values between 0 and 1 . This contributes to the weighted calculation of the future urban sustainable development index. Bearing in mind that the indicator scores cannot be based solely 
on numerical data, the evaluation of the status quo is based on the degree to which the current data has met the targets set in the mid-term plan for Zhoushan's development as well as the index standards at home and abroad, with the comprehensive expert opinion assisting in the development of indicator-scoring standards.

\section{Results and discussion}

Using the sustainable development indicator system established above, this study has calculated standardized values for each indicator through standard data processing. The values for the Domain Layer, Dimension Layer, and Target Layer were obtained through weighted summation. The original data used in the evaluation was derived from the Zhoushan Statistical Yearbook and various government agencies, such as the Zhoushan Environmental Protection Bureau, the Production Safety Supervision Bureau, and the Bureau of Statistics. The scores for each dimension layer and from 2009 to 2017 are shown in Figure 5.

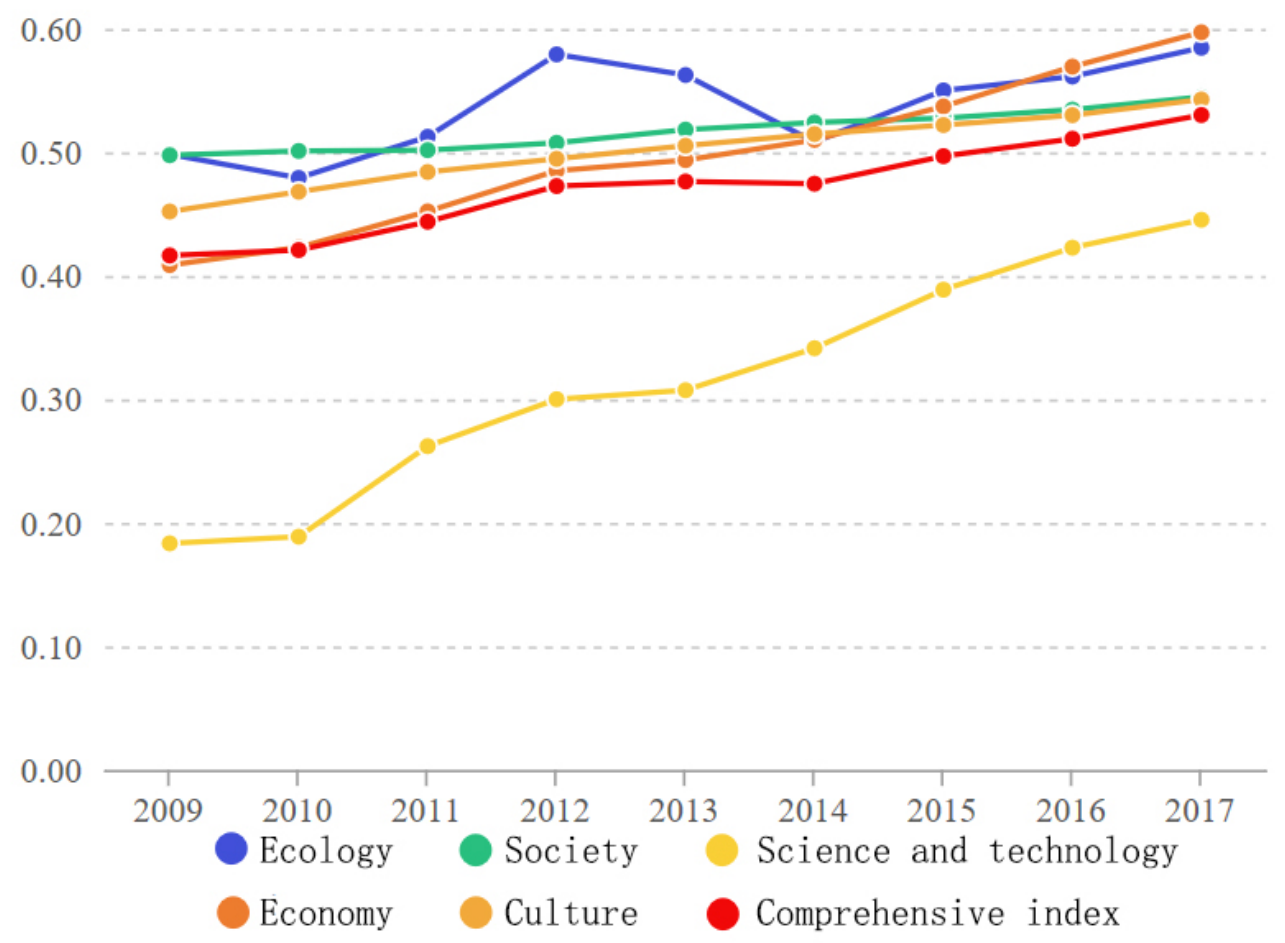

Figure 5: Changing trend map of comprehensive index of Zhoushan sustainable development capability and evaluation index of various dimensions from 2009 to 2017.

As can be seen from Figure 5, since 2009, the sustainable development index of Zhoushan City has generally shown a slow growth trend. However, according to the results of the composite index of 0.53 (total score equals 1), Zhoushan is still at a relatively basic developmental stage, with development of the scientific and technological dimension lagging a bit behind. Among the five dimensions, the ecological sustainable development index shows a fluctuating upward trend, with little increase and no obvious effect. In 2012, the ecological sustainable development index dropped considerably, mainly due to the strong developmental momentum of Zhoushan industry during the $12^{\text {th }}$ Five-Year Plan period, but the pollutant treatment facilities did not keep up with these changes. It also shows that the development of 
urban economy and society at this stage may be based on the sacrifice of the environment. The social, economic, and cultural levels reflect a relatively stable trend of development. Although foreign trade volume increases, the proportion of foreign direct investment decreases, resulting in a slowing of the increase of the index of sustainable economic development. The overall value added is, however, considerable. The science and technology dimension undergoes the most rapid development, which may be related to the background trend of science and technology innovation in the country as a whole. In 2013, the Zhoushan government issued relevant policies such as the 'China (Zhoushan) Marine Science City Construction Implementation Plan'中国 (舟山) 海洋科学城建设实施方案, which has brought about a surge in science and technology development. Even so, science and technology belong to the weakest sector of Zhoushan's overall development.

On the basis of these results, this paper evaluates the current construction of specific indicators of Zhoushan. The results of each dimension are shown in Figures 6-10. They are drawn to reflect the relationship between the highest possible score and the current score for Zhoushan. The outer frame in light blue represents the best that Zhoushan can achieve, while the inner frame in dark blue represents Zhoushan's current status score.
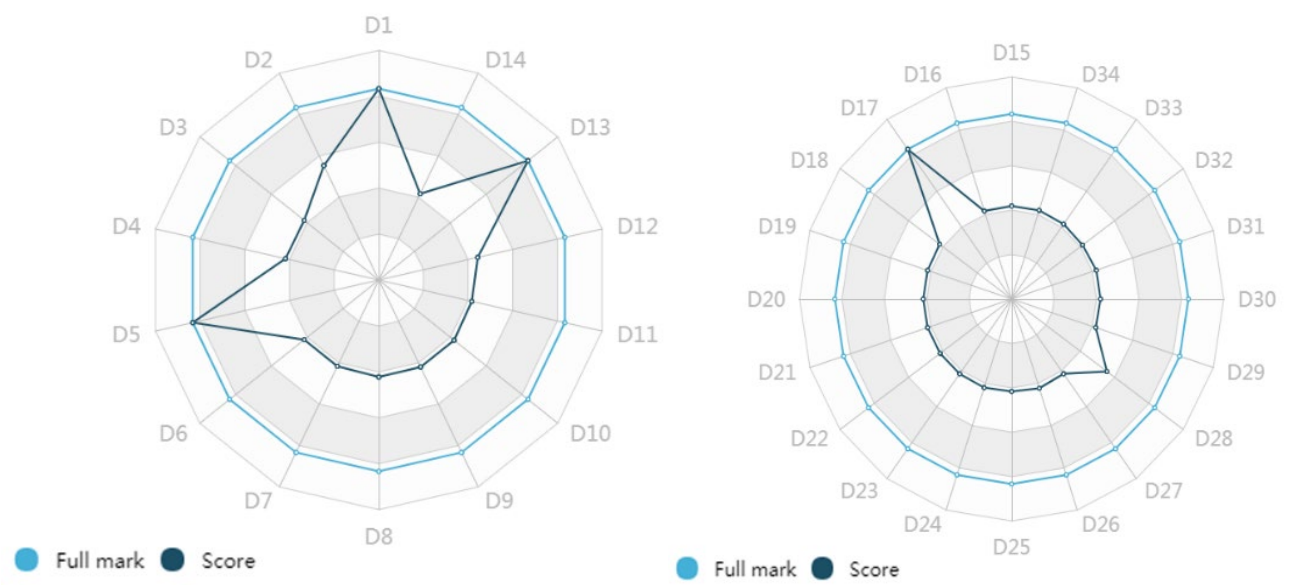

Figure 6: The current status of each field in the ecological dimension (left).

Figure 7: Current status of each field in the social dimension (right).
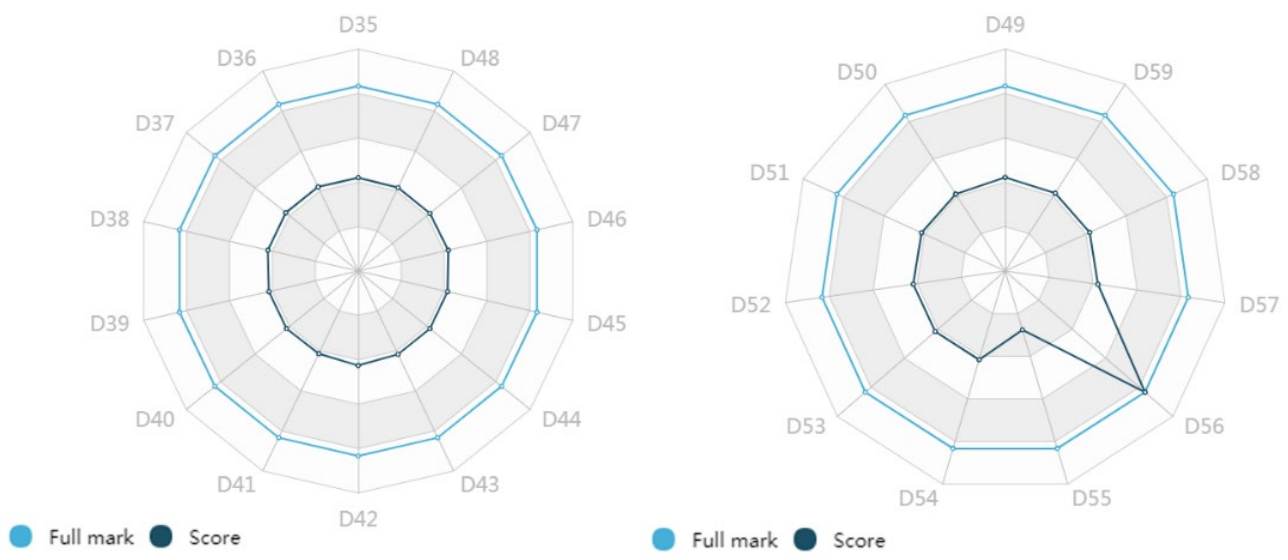

Figure 8: Current status of each field in the economic dimension (left).

Figure 9: Current status of each field in the cultural dimension (right). 


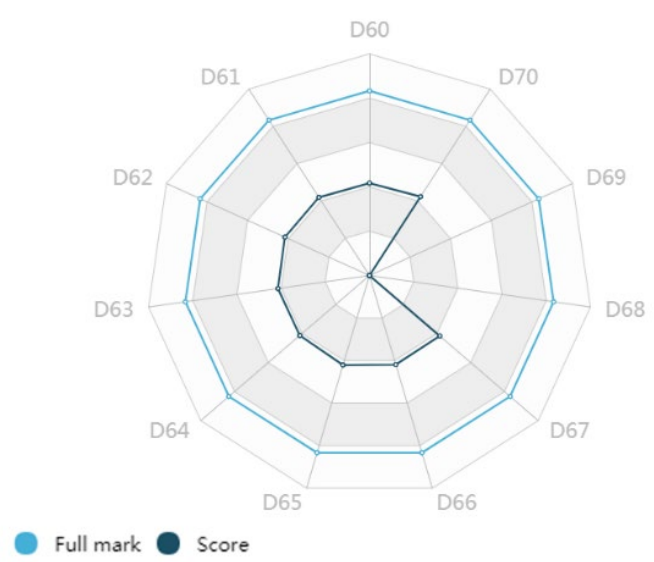

Figure 10: Current status of each field in the scientific and technological dimension.

Analysis of the current construction of Zhoushan Maritime Garden City shows that Zhoushan has good ecological foundations, but there remains room for improvement in the urban built environment, such as urban greening level (D6-D7), and environmental protection management mechanisms related to ecological space restoration (D10) and pollutant treatment (D11, D13). From a societal perspective, Zhoushan's investment in social infrastructure construction has grown markedly, and the conditions of transportation facilities and public service facilities have improved significantly in recent years. However, due to the low starting point and historical debts, some infrastructure bottlenecks in Zhoushan City remain. On the one hand, there is a significant safety (D15, D16, D18) risk for the people of Zhoushan. On the other hand, the integration of production and industry into the city itself is insufficient and it has not been possible to meet needs for daily commuting (D19-D26) and leisure, which greatly reduces residents' happiness.

At present, although Zhoushan's economy shows an upward trend and accelerating pace of development, the developmental level (D35-D38) remains far behind other cities and counties in Zhejiang Province. In particular, the overall developmental level of marine emerging industries in the new urban area (D44-D48) is low, and the ability to attract investment is poor (D39-D42), which indicates that a genuinely open urban economic system has not yet formed. With the acceleration of urbanization in Zhoushan, the unsustainability of culture and science and technology will be a major obstacle for Zhoushan's future development. Across the fields of historical and cultural inheritance (D49-D51), cultural communication (D52-D54), and facility friendliness (D56-D59), Zhoushan's government has failed to invest at a level that is appropriate for the current level of urbanization. In terms of science and technology, the value added from Zhoushan's high-tech industry and the funds for research and experimental development (D60) have been significantly increased. At present, however, the international scientific and technological platform for the marine industry and the corresponding supporting system (D61-D65) have not been well constructed, and the number of high-skilled marine scientific and technological laboratories (D66-D67) are clearly lagging behind other marine cities. Based on Zhoushan's development over the years, it is found that the trend of the sustainable development index in each dimension is consistent with reality, which suggests that the construction of this index has certain rationality. 
The deep reasons for the problems facing the state in terms of sustainable development can be summarized as follows:

Conception: A city is a dynamic system composed of various interdependent subsystems, such as ecology, economy, society, culture, and science and technology. It is difficult to achieve the desired results if we only focus on particular major problems in the operation of the city, rather than on the system as a whole. In the past, Zhoushan paid too much attention to economic growth but neglected multidimensional coordinated development that integrated ecology, society, culture, and science and technology.

Planning regulations: The complexity of the sustainable development system requires coordination and cooperation among different departments. However, in the actual process, institutional gaps and conflicts mean that there is often no consensus among departments, resulting in lax rules and regulations. Therefore, we must speed up the implementation integrated planning, coordinating Sustainable Development Planning with National Economic and Social Development Planning, Urban and Rural Planning, Ecological Environment Protection Planning, and Land Use Planning.

Leadership: Improving the authority and legality of planning is of vital importance for the sustainable development of cities. Systematic softening, arbitrary planning changes, and insufficient awareness of sustainable development of enterprises and residents will greatly undermine the realization of sustainable development goals.

\section{Conclusions and suggestions}

This paper has advanced an urban sustainable development indicator system for the construction and development of Zhoushan Maritime Garden City. In the process of establishing the indicator system, we referred to authoritative international indices, such as the Global City Competitiveness Index, as well as city indicator systems in both China and overseas. We also engaged in discussions with experts, scholars, and government departments. Finally, we proposed a set of 71 indicators for Zhoushan on the basis of the city's specific island characteristics, such as the archipelago's spatial and locational advantages when it comes to marine industries and its limited land area and transport connections. Because this paper only selects some indicators to characterize the current situation of sustainable development and because sustainability indicators change greatly over time, it is necessary to make corresponding adjustments and continually monitor the goals of the indicator and of the sustainable development initiative as a whole. In particular, the generalizability of the indicators requires further study as well as the sensitivity of the results to changes in the indicators and especially in the weightings.

The sustainable development indicator system for the Zhoushan Maritime Garden City in this study can serve several purposes. It can comprehensively consider the specific developmental indices and mission requirements for each city department as well as define the responsible departments for each indicator. This permits an objective evaluation of Zhoushan Maritime Garden City's current stage of development, thereby informing the comprehensive evaluation and assessment of the work performance of the district, county (city) party committee, and government. The indicator system can also evaluate the characteristics and achieved progress toward sustainable development in Zhoushan and then provide foundations for the municipal party committee and 
municipal government to make development policy decisions and guide the city's future development trajectory. The applications of this indicator system in Zhoushan Archipelago in particular are thus to some extent specific to the Chinese administrative context; if applied to other governmental contexts, the indicator system's potential uses and effectiveness would differ.

By applying the indicator system of Zhoushan Maritime Garden City development as the basic factor in the top-level design, we can gain some insights into macro-level control over the economy, environment, society, culture, and science and technology in the process of planning and design. This also allows contributions toward establishing an urban sustainable development model suited to a particular archipelagic city. Attentiveness to the status of core indicators can help improve the quality of urban development. This indicator system focuses on the implementation of sustainable development across all aspects of urban development, which provides both good foundations for constructing more scientific, accurate, and comprehensive evaluation index systems in the future and guiding urban sustainable development elsewhere.

Evaluating Zhoushan's sustainable development using the proposed index indicates that science, technology, and culture in Zhoushan are currently relatively underdeveloped and that it is necessary to strengthen these through relevant policies in the future. In making recommendations, it is nonetheless important to always consider the limitations of the research design and results.

From an urban development perspective, recognition of spatiotemporal change is crucial to achieving sustainable development goals (Lee \& Huang, 2007). We must evaluate the state of the island city through dynamic indicators. This paper builds its corresponding index on the basis of today's Zhoushan alone. As such, it is vital to re-examine sustainability indicators and assess their applicability in the light of new urban development strategies over the course of several years. Only in this manner can we effectively reflect the new context and dynamics of urban sustainable development.

\section{Acknowledgments}

This work was supported by the Key Program of the National Social Science Foundation of China (No.16ZDA018).

\section{References (English)}

Baldacchino, G., \& Kelman, I. (2014). Critiquing the pursuit of island sustainability: Blue and green, with hardly a colour in between. Shima, 8, 1-21.

Barbier, E. B., Koch, E. W., Silliman, B. R., Hacker, S. D., Wolanski, E., \& Primavera, J., et al. (2008). Coastal ecosystem-based management with nonlinear ecological functions and values. Science, 319(5861), 321-323. https://doi.org/10.1126/science.1150349

Barragán, J. M., \& de Andrés, M. (2015). Analysis and trends of the world's coastal cities and agglomerations. Ocean \& Coastal Management, 114, 11-20. https://doi.org/10.1016/j.ocecoaman.2015.06.004

Barrera-Roldán, A., \& Saldivar-Valdés, A. (2002). Proposal and application of a Sustainable Development Index. Ecological Indicators, 2(3), 251-256. https://doi.org/10.1016/s1470$\underline{160 x(02) 00058-4}$ 
Bélanger, V., Vanasse, A., Parent, D., Allard, G., \& Pellerin, D. (2012). Development of agrienvironmental indicators to assess dairy farm sustainability in Quebec, Eastern Canada. Ecological Indicators, 23, 421-430. https://doi.org/10.1016/j.ecolind.2012.04.027

Bell, S., \& Morse, S. (2012). Sustainability indicators: Measuring the immeasurable?. Routledge. London: Earthscan.

Briassoulis, H. (2001). Sustainable development and its indicators: Through a (planner's) glass darkly. Journal of Environmental Planning and Management, 44(3), 409-427. https://doi.org/10.1016/j.landurbplan.2012.02.009

Brunelli, M. (2015). Introduction to the analytic hierarchy process. Cham: Springer.

Caprotti, \& Federico. (2016). Defining a new sector in the green economy: Tracking the techno-cultural emergence of the cleantech sector, 1990-2010. Technology in Society. https://doi.org/10.1016/j.techsoc.2016.04.007

Cochrane, P. (2006). Exploring cultural capital and its importance in sustainable development. Ecological Economics, 57(2), 318-330. https://doi.org/10.1016/j.ecolecon.2005.04.012

Davidson, F. (1996). Planning for performance: Requirements for sustainable development. Habitat international, 20(3), 445-462.

Fernandes, R., \& Pinho, P. (2017). The distinctive nature of spatial development on small islands. Progress in Planning, 112, 1-18. https://doi.org/10.1016/j.progress.2015.08.001

Garner, P. (1997). Sustainability, the environment and urbanization. BMJ Clinical Research, 314(7080), 615.

Gibson, R. B. (2006). Sustainability assessment: Basic components of a practical approach. Impact Assessment and Project Apraisal, 24(3), 170-182. https://doi.org/10.3152/147154606781765147

Grydehøj, A. (2015). Island city formation and urban island studies. Area, 47(4), 429-435. https://doi.org/10.1111/area.12207

Grydehøj, A., \& Casagrande, M. (2019). Islands of connectivity: Archipelago relationality and transport infrastructure in Venice Lagoon. Area. Epub ahead of print. https://doi.org/10.1111/area.12529

Grydehøj, A., \& Kelman, I. (2017). The island eco-trap: Climate change mitigation and conspicuous sustainability. Area, 49, 106-113. https://doi.org/10.1111/area.12300

Grydehøj, A., \& Kelman, I. (2016). Island smart eco-cities: Innovation, secessionary enclaves, and the selling of sustainability. Urban Island Studies, 2, 1-24. https://doi.org/10.20958/uis

Hardoy, J. E., Mitlin, D., \& Satterthwaite, D. (1992). Environmental problems in Third World cities. London: Earthscan.

Jin, Y. (2008). Ecological civilization: From conception to practice in China. Clean Technologies and Environmental Policy, 10(2), 111-112. https://doi.org/10.1007/s10098-008-0147-6

Johnson, H. (2019). Islands of design: Reshaping land, sea and space. Area. Epub ahead of print. https://doi.org/10.1111/area.12477

Landeta, J. (2006). Current validity of the Delphi method in social sciences. Technological Forecasting and Social Change, 73(5), 467-482. https://doi.org/10.1016/j.techfore.2005.09.002

Larjosto, V. (2019). Islands of the Anthropocene. Area. Epub ahead of print. https://doi.org/10.1111/area.12515

Lee, Y. J., \& Huang, C. M. (2007). Sustainability index for Taipei. Environmental Impact Assessment Review, 27(6), 505-521. https://doi.org/10.1016/j.eiar.2006.12.005 
Li, F., Liu, X., Hu, D., Wang, R., Yang, W., Li, D., \& Zhao, D. (2009). Measurement indicators and an evaluation approach for assessing urban sustainable development: A case study for China's Jining City. Landscape and Urban Planning, 90(3-4), 134-142. https://doi.org/10.1016/j.landurbplan.2008.10.022

Li, X., Lin, T., Zhang, G., Xiao, L., Zhao, Q., \& Cui, S. (2011). Dynamic analysis of urban spatial expansion and its determinants in Xiamen Island. Journal of Geographical Sciences, 21(3), 503-520. https://doi.org/10.1007/s11442-011-0860-7

Linstone, H. A., \& Turoff, M. (eds.) (1976). The Delphi method: Techniques and applications. London: Addison-Wesley.

Liu, Z. L., Dai, Y. X., Dong, C. G., \& Qi, Y. (2009). Low-carbon city: Concepts, international practice and implications for China. Urban Studies, 16(6), 1-7.

Maclaren, V. W. (1996). Urban sustainability reporting. Journal of the American Planning Association, 62(2), 184-202. https://doi.org/10.1080/01944369608975684

Moldan, B., Janoušková, S., \& Hák, T. (2012). How to understand and measure environmental sustainability: Indicators and targets. Ecological Indicators, 17, 4-13. https://doi.org/10.1016/j.ecolind.2011.04.033

Plummer, R. (2006). The evolution of sustainable development strategies in Canada: an assessment of three federal natural resource management agencies. Sustainable Development, 14(1), 16-32. https://doi.org/10.1002/sd.269

Saaty, T. L. (2014). Analytic heirarchy process. Wiley statsRef: Statistics reference online. https://doi.org/10.1002/9781118445112.stat05310

Shen, Q. (2013). Study on New Urbanization based on Ecological Civilization. Urban Planning Forum, 1, 29-36.

Sheng, N., Tang, U. W., \& Grydehøj, A. (2017). Urban morphology and urban fragmentation in Macau, China: Island city development in the Pearl River Delta megacity region. Island Studies Journal, 12, 199-559. https://doi.org/10.24043/isj.25

Spangenberg, J. H. (2002). Institutional sustainability indicators: an analysis of the institutions in Agenda 21 and a draft set of indicators for monitoring their effectivity. Sustainable Development, 10(2), 103-115. https://doi.org/10.1002/sd.184

Spangenberg, J. H., Pfahl, S., \& Deller, K. (2002). Towards indicators for institutional sustainability: lessons from an analysis of Agenda 21. Ecological indicators, 2(1-2), 61-77. https://doi.org/10.1016/s1470-160x(02)00050-x

Sun Z., \& Ma H. (2018). Assessment of the sustainable development of the Beijing-TianjinHebei urban agglomeration based on a back propagation neural network. Acta Ecologica Sinica, 38(12), 4434-4444. https://doi.org/10.5846/stxb201802050302

Ukaga, O., \& Maser, C. (2004). Evaluating sustainable development: Giving people a voice in their destiny. Sterling, VA: Stylus.

UNCED (1992). Report of the United Nations Conference on Environment and Development. Rio de Janeiro: United Nations.

United Nations Department of Economics (2007). Indicators of sustainable development: Guidelines and methodologies. New York: United Nations.

Venturelli, R. C., \& Galli, A. (2006). Integrated indicators in environmental planning: Methodological considerations and applications. Ecological indicators, 6(1), 228-237. https://doi.org/10.1016/j.ecolind.2005.08.023 
Wang, J., \& Liu, Y. (2013). Tourism-led land-use changes and their environmental effects in the southern coastal region of Hainan Island, China. Journal of Coastal Research, 29(5), 11181125. https://doi.org/10.2112/jcoastres-d-12-00039.1

Yigitcanlar, T., \& Dur, F. (2010). Developing a sustainability assessment model: The sustainable infrastructure, land-use, environment and transport model. Sustainability, 2(1), 321-340. https://doi.org/10.3390/su2010321

Zhao, B., Kreuter, U., Li, B., Ma, Z., Chen, J., \& Nakagoshi, N. (2004). An ecosystem service value assessment of land-use change on Chongming Island, China. Land Use Policy, 21(2), 139-148. https://doi.org/10.1016/j.landusepol.2003.10.003

\section{References (Chinese)}

丁玉洁. (2009). 我国生态城市建设的内涵、特点及面临的挑战. 中国环境科学学会学术 年会.

李天星. (2013). 国内外可持续发展指标体系研究进展. 生态环境学报, 22(6), 1085-1092. 吝涛, 薛雄志, 崔胜辉, \& 石龙宇. (2009). 快速城市化进程中海岛景观格局变化研究. 海洋 环境科学, 28(1), 87-91.

孙晓, 刘旭升, 李锋, \& 陶宇. (2016). 中国不同规模城市可持续发展综合评价. 生态学报, $36(17), 5590-5600$.

孙湛, \& 马海涛. (2018). 基于 BP 神经网络的京津冀城市群可持续发展综合评价.生态学 报, 38(12), 343-353.

王晶, 张峰, 李佳芮, 孙梅, 孙苗, \&王泉斌. (2019). 我国海岛县域经济发展特征与问题. 海 洋通报, 38(03), 250-256

吴凡, \& 苗韧. (2017). 城市可持续发展能力评估体系构建研究. 生态经济, 33(03),105-109. 吴一洲, 陈前虎, 武前波, \& 汤燕. (2013). 生态海岛的紧凑多中心城市空间转型策略探索一以舟山国家新区“海上花园城”建设为例,城市发展与规划大会.

吴忠泽. (2006). 科技创新是 21 世纪城市可持续发展的源泉和动力. 中国软科学,(09),1317.

郑晓云, 杜娟, \& 苏义坤. (2018). 基于改进熵权法的城市可持续发展评价一一以哈尔滨市 为例. 土大工程与管理学报, 35(04), 65-71.

中国城市发展研究院（CCDA）。（2010）。2010 年中国城市科学发展综合评价报告, 社会科学出版社, 北京

中国城市发展研究院. (2010). 2010 中国城市科学发展综合评价报告. 中国社会科学出版 社.

张志强, 程国栋, \& 徐中民. (2002). 可持续发展评估指标、方法及应用研究. 冰川冻土, 24(4), 344-360.

中国自然资源部. (2018). 海岛统计调查公报(2017). 中国：自然资源部.

舟山市政府. (2017). 关于建设海上花园城市的指导意见(2017). 中国浙江：舟山市政府. 朱丽. (2018). 2000-2015 年广州城市低碳可持续发展进程研究. 生态环境学报, 27(05). 957-963. 